\title{
РЕЦЕНЗИЯ НА КН.: АЛБОГАЧИЕВА М. С.-Г. ИСЛАМ В ИНГУШЕТИИ: ЭТНОГРАФИЯ И ИСТОРИКО-КУЛЬТУРНЫЕ АСПЕКТЫ. СПБ.: МАЭ РАН, 2017. - 264 С. *
}

Современное исламоведение в России до сих пор не стало крупным научным направлением. Мы можем назвать немного специалистов, которые активно работали и продолжают работать либо в области истории ислама в Российской империи (Д.Ю. Арапов, В.О. Бобровников, А.К. Аликберов), либо в сфере антропологических исследований нынешнего исламского возрождения, которые занимаются отдельными северокавказскими регионами или народами (А.А. Ярлыкапов, И.Л. Бабич, М.Ю. Рощин и др.). Можем также упомянуть очень компетентный и профессиональный журнал «Исламоведение», издаваемый в Дагестане. Поэтому выход книги, объектом изучения которой стала история ислама и современное состояние мусульманской жизни в Республике Ингушетия, - безусловно, событие крупное и важное. Ее автор - историк, этнограф, ведущий специалист-кавказовед Музея антропологии и этнографии (Кунсткамеры) РАН, кандидат исторических наук Макка Султан-Гиреевна Албогачиева. Автор много лет трудилась под руководством известного российского кавказоведа, доктора исторических наук Юрия Юрьевич Карпова. К сожалению, Юрий Юрьевич рано ушел от нас - в 2015 г. в возрасте 60 лет, но успел оставить не только собственные фундаментальные труды по истории Северного Кавказа (главным образом, Дагестана), но и создать свою научную школу, вырастить новые кадры, составляющие в настоящее время основу отдела этнографии Кавказа МАЭ РАН.

Монография М.С.-Г. Албогачиевой посвящена исследованию ислама в Ингушетии: истории и современности. Рецензируемая книга имеет продуманную структуру: в ней шесть глав, которые постепенно раскрывают перед нами различные стороны объекта изучения кавказоведа. Автор рассматривает историю распространения ислама среди ингушей в прошлые века, дает характеристику основных религиозных братств, возникших в этом регионе, останавливается на религиозных институтах, сложившихся в Республике Ингушетия в 1990-2010-е годы, и наконец, три последние главы посвящены различным сторонам «жизни» и «практике» ислама в ингушском обществе: особенностям проведения мусульманских праздников (Ураза-байрам и Курбан-байрам), характеристике ритуальных праздников, специфике строительства мечетей в современной Ингушетии и бытованию ингушских традиций в исламском контексте (в первую очередь, обряда жизненного цикла). В результате такого планомерного подхода у читателей создается комплексное видение ислама в Ингушетии.

Бабич Ирина Леонидовна - д.и.н., главный научный сотрудник Института этнологии и антропологии РАН (Москва, Ленинский просп., 32-A). Электронная почта: babich@iea.ras.ru Babich, Irina L. - Institute of Ethnology and Anthropology, RAS (Moscow, Leninsky prospect, 32a).E-mail: babich@iea.ras.ru

* Публикуется в соответствии с планом научно-исследовательских работ Института этнологии и антропологии РАН 
Автор подчеркивает, что в настоящее время ислам в жизни ингушей играет важную роль, «пронизывая все сферы жизни, общественные и семейные отношения, обычаи и традиции» (с. 5). Более того, в Ингушетии ислам настолько связан с национальными ценностями, что его возрождение способствовало и росту национального самосознания. Это интересный феномен, так как на Северо-Западном Кавказе рост исламских общин в 1990-2000-е гг. отчасти ослаблял этнические аспекты жизни народов: исламские ценности подчас противопоставлялись национальным, отчасти отвергая последние (Бабич, Ярлыкапов 2003: 183). Однако на Северо-Восточном Кавказе в постсоветское время сложилась иная национально-религиозная ситуация. Свойственное западным регионам Северного Кавказа противоречие между этническими и исламскими ценностями и традициями на востоке, хотя тоже имело место, но не стало сильным фактором, оказывающим существенное влияние на жизнь народов. В конечном счете, исламские и национальные лидеры нашли общий язык в едином движении по возрождению народов Северо-Восточного Кавказа.

В рецензируемой монографии широко использованы разные типы источников: в первую очередь, это ёные материалы, которые автор выявил в ряде архивов России (Российском государственном историческом архиве, Центральном государственном архиве Республики Северной Осетии-Алания и др.). Во-вторых, это собранные в течение 15 лет автором полевые этнографические материалы. К сожалению, эти материалы не всегда грамотно оформлены в самой монографии: иногда просто отсутствуют ссылки на них, что отчасти ослабляет безусловно сильное впечатление от ознакомления с книгой. Историографический обзор в работе - крайне мал. Можно было более детально остановиться на работах предшественников. Причем в самой книге довольно много ссылок на эти работы и в целом читатель получает представление о том, что было ранее сделано по данной теме.

В первой главе М. С.-Г. Албогачиева показывает сложное и уникальное сочетание различных религиозных направлений и их внедрение в ингушское общество в исторической ретроспективе. Ингушское общество оказалось объектом религиозного воздействия самых разных религиозных направлений, которые, с одной стороны, внедрялись в разные периоды истории и соответственно этот процесс был растянут во времени, а с другой, религии накладывались одна на другую, порождая необычайный синкретизм и сложное переплетение в жизни, быту и сознании ингушей. Автор показывает глубокий языческий слой, возникший у народа в прежние века. Его пласт сохранялся вплоть до XX в. М. С.-Г. Албогачиева отмечает, что еще в 1920-е гг. в Горной Ингушетии жили последние языческие жрецы. До сих пор в Ингушетии сохраняются языческие святилища XIII-XIV вв. (например, святилище Мятцели). На наш взгляд, это очень любопытное явление. Сравнивая с тем, что происходит в соседней с Ингушетии - Осетии, где в последнее десятилетие произошел мощный подъем языческого пласта осетинской культуры, на базе которого осетинские идеологи стремятся возродить осетинский этнос, мы видим, что в Ингушетии этого не происходит. Древнее язычество ингушей не стало инструментом возрождения ингушей в настоящее время. С XI в. в Ингушетии стали появляться христиане, а с XII в. в регионе уже работали грузинские миссионеры. До сих пор, как пишет автор монографии, на храме Тхаба-Ерды сохранились надписи, сделанные на древнегрузинском языке. Впоследствии христианизацию ингушей продолжила Российская империя. Однако несмотря ни на грузинские, ни на российские усилия, 
христианство не смогло укорениться в ингушском обществе. Автор обнаружила в архивах многочисленные материалы, датируемые первой половиной XIX в., свидетельствующие о просьбах ингушей перейти из православия в ислам. К сожалению, М. С.-Г. Албогачиева не останавливается на причинах данного процесса, хотя это позволило бы понять, почему в соседнем - осетинском обществе христианизация проходила более успешно. Социально-политические и экономические факторы бытования православия во многом были сходными в осетинском и ингушском обществах, однако результат - разный.

Первые данные о проникновении ислама к ингушам автор датирует VII в. и это был Дагестан. Значительно позднее, уже в XVIII в. наблюдалось значительное влияние на ингушей со стороны чеченцев и чеченского шейха Мансура, затем - Шамиля. При описании распространения ислама автор задумывается о вопросе: почему «поздний» ислам у ингушей сумел завоевать все предыдущие религиозные пласты? Причем распространение ислама в ингушских общинах происходило в течение всего XIX в, когда уже Россия была активным игроком на Северном Кавказе и всячески контролировала и ограничивало развитие ислама в регионе (подр. об этом см.: Аpaпов 2007). Это уникальное явление, которое до сих пор представляет научный интеpec, и, на наш взгляд, до конца не изученное. Автор впервые пытается в своей монографии ответить на данный вопрос. Как быстро чеченские братства (вирды) сумели внедриться в ингушском обществе? Как влиял на ингушей Кунта-хаджи Кишиев из Чечни, распространяя кадирийский тарикат? Ведь между ингушами и чеченцами были сложные отношения, которые могли препятствовать проникновению ислама со стороны Чечни. Переломным периодом для ингушского ислама, как пишет автор, стала середина XIX в. - время активного воздействия на ингушей со стороны Российской империи и в то же время все ингушские общества к этому времени приняли ислам (с. 5). Причем, как сам автор справедливо подчеркивает, ингуши не были активными противниками Российской империи (с.39) и приобрели статус «покорных» достаточно «легко» для империи и даже участвовали в сражениях против других народов на стороне российской армии (РГВИА. Ф. 13454. Оп. 6. Д. 83. Л. 1, 5, 6-8). Во второй половине XIX в. в Ингушетии, как сообщает автор монографии, уже появилась собственная мусульманская элита (с. 45). И в этом процессе основная роль принадлежала суфийским чеченским шейхам.

В результате к началу ХХ в. в Ингушетии сложилась очень тонкая и отчасти противоречивая ситуация, при которой в регионе могли одновременно сосуществовать и язычники, и христиане, и мусульмане. Автор справился с описанием этого сложнейшего процесса, в котором были переплетены различные религиозные идеологии и практики.

Важно отметить, что М. С.-Г. Албогачиева прослеживает историю всех трех религиозных направлений плоть конца 1980-х годов - окончания существования СССР и показывает неоднозначность и специфичность процессов, имевших место в это время в контексте всеобего ограничения религиозной жизни в стране в целом. Во-первых, автор отмечает, что вплоть до 1980-х гг. среди ингушей сохранялись местные суфийские практики (с. 59), во-вторых, во времена депортации ингушей в Среднюю Азию желающие могли получить мусульманское образование в Ташкенте и Бухаре. Таким образом, вернувшись на Родину, в ингушском обществе уже были мусульмане, владеющие основами мусульманских знаний. 
Описывая исторический контекст религиозности ингушей, тем не менее автор, по нашему мнению, некорректно присоединил один из народов Северо-Восточного Кавказа - карабулаков к ингушам (с. 39, 42). Как свидетельствуют многочисленные архивные материалы, почерпнутые нами в Российском государственном военно-историческом архиве, российская администрация всегда отделяла карабулаков и от ингушей, и от чеченцев, выделяя их как объект и субъект российской геополитики. Между тем автор пишет, что «активными сторонниками имама Шамиля были карабулаки (этническое подразделение ингушского народа)». Во-вторых, карабулаки, получили отдельное воззвание от Шамиля, в котором он призывал его поддержать. Шамиль подготовил отдельные воззвания от своего имени и ингушам, и карабулакам, что также свидетельствует о том, что не только Российская империя, но и исламские лидеры Северного Кавказа рассматривали карабулаков в качестве отдельного субъекта и объекта геополитики (РГВИА. Ф. 13454. Оп. 6. Д. 287. Л. 1-2, 3-5).

Далее автор приступает к изучению современного состояния исламской жизни в Ингушетии, подчеркивая практическое слияние ислама как идеологии и институций с местной (республиканской) властью. М. С.-Г. Албогачиева указывает четко: в 1990-2000-е годы «ислам был допущен и включен в систему власти и подчинялся власти» (с. 61). Автор дает характеристику двух тарикатов, которые распространились в регионе: это суфийские братства - нашкбандийа и кадририйа. Кадирийский тарикат пришел в Ингушетию в период Кавказской войны из Чечни, накшбандийа - из Дагестана. В основе всех суфийских практик лежит духовное упражнение - зикр (повторение имени Бога или некоторых фраз из Корана). Первое братство исполняет громкий зикр, второй - тихий. Значимость данной главы трудно переоценить для читателей, поскольку автор подробно описывает данные религиозные практики, в том числе и исполнение зикра, ритуальных песнопений в Ингушетии. Поскольку эти практики носят в России очень ограниченный, локальный характер, о них очень мало знают. Для широкого читателя это будет очень интересно. Автор рецензии вместе с автором монографии несколько лет тому назад присутствовал на исполнении громкого зикра мусульманами-ингушами в Санкт-Петербурге. Это производит сильное впечатление. Макка Албогачиева анализирует современное состояние двух тарикатов в Ингушетии и описывает историю и современное состояние института хаджа. Автор приходит к выводу, что зикр играет огромную роль в консолидации современного ингушского общества. В нем как в многогранном явлении заложены самые различные функции. И в первую очередь, ритуальные практики - это «социально значимое средство, служащее для поддержания общих норм и ценностей народа» (с. 222).

В третьей главе описаны исламские институции - современный Муфтият, и что особенно ценно - современный Кадият (шариатский суд). Ингушетия - единственная республика в постсоветской России, где в течение двух лет - 1999-2000 гг. официально работал шариатский суд. Впоследствии российские юридические власти потребовали привести законность в Ингушетии в соответствии с российским законодательством, в котором нет права создавать такие суды.

В последующих главах М. С.-Г. Албогачиева останавливается на практике проведения в Ингушетии мусульманских праздников: Ураза-байрам и Курбан-байрам, а также практике посещения святых мест - могил и мавзолеев исторических и мифических деятелей ислама в Ингушетии. Данные описания основаны на широких этнографических материалах, собранных автором в Ингушетии. Автором изучены 
архитектурные стили и этапы строительства новых мечетей в Ингушетии. И наконец, описаны обряды жизненного цикла ингушей (рождение, брак и развод, похороны и поминки), которые во многом связаны с адатом и лишь отчасти - с исламом.

При описании ингушских обрядов мы опять сталкиваемся с проблемой соотношения национального и религиозного пластов жизни народов Северного Кавказа. Известно, что ханафитский ислам, который распространен среди многих народов России, например, среди татар и адыгов, имеет достаточно толерантное отношение к народным обрядам и традициям, где он распространялся. Однако у ингушей распространился шафиитский ислам, который, как считается, жестче относится к обычаям. Тем не менее на примере ингушей мы видим, что это не совсем так. В современном ингушском обществе, как отмечает автор, «часть населения выражает недовольство в отношении некоторых обрядов, не соответствующих нормам ислама, считая, что в них много элементов язычества» (с. 222). Таким образом, М. С.-Г. Албогачиева все же признает, что и в ингушском обществе есть некоторое противостояние между суфийским и т.н. «народным» исламом.

Мы можем заключить, что до сих пор не было специальных исследований, посвященных исламу в Ингушетии. Монография М. С.-Г. Албогачиваевой «Ислам в Ингушетии: этнография и историко-культурные аспекты» - это первое фундаментальное исследование антрополога-кавказоведа. В нем предпринята достаточно успешная попытка реконструировать структуру ингушского пантеона, этапы христианизации и исламизации в разные периода истории Ингушетии. Монография станет крупным событием в становлении российского исламоведения.

\section{Материалы и источники}

РГВИА. Ф. 13454. Оп. 6. Д. 83. Л.1, 5, 6-8 - Российский государственный военно-исторический архив. Ф. 13454. Оп.6. Д. 83. Л.1, 5, 6-8.

РГВИА. Ф. 13454. Оп. 6. Д. 287. Л. 1-2, 3-5 - Российский государственный военно-исторический архив. Ф. 13454. Оп. 6. Д. 287. Л. 1-2, 3-5.

\section{Научная литература}

Бабич И.Л., Ярлькапов А.А. Исламское возрождение в современной Кабардино-Балкарии. М., 2003. $183 \mathrm{c}$.

Арапов Д.Ю. и др. (авт. кол.) Северный Кавказ в составе Российской империи. М.: Новое лит. обозрение, 2007. 460 c.

\section{References}

Babich, I.L., and A.A. Yarlykapov. 2003. Islamskoe vozrozhdenie v sovremennoi KabardinoBalkarii [Islamic revival in modern Kabardino-Balkaria]. Moscow.

Arapov D.Yu. and et. al. 2007. Severnyi Kavkaz v sostave Rossiiskoi imperii [The North Caucasus as part of the Russian Empire]. Moscow: Novoe literaturnoe obozrenie. 